2015 LAF CSI Program Landscape Performance Series:

The George Bush Presidential Library, Dallas, TX

Research Title: The University of Texas at Austin's Case Study Investigation 2015:

The George W. Bush Presidential Center, Dallas, TX

Research Fellow:

Allan W. Shearer, M.L.A., Ph.D., ALSA

Associate Professor \& Co-Director of the Center for Sustainable Development

The University of Texas at Austin

School of Architecture

\title{
Research Assistant:
}

Neive Tierney, MLA candidate

\section{Case Study Partners:}

Project Firm: Michael Van Valkenburgh Associates, Inc., Herb Sweeny, Sponsor/Research Partner: Landscape Architecture Foundation (LAF)

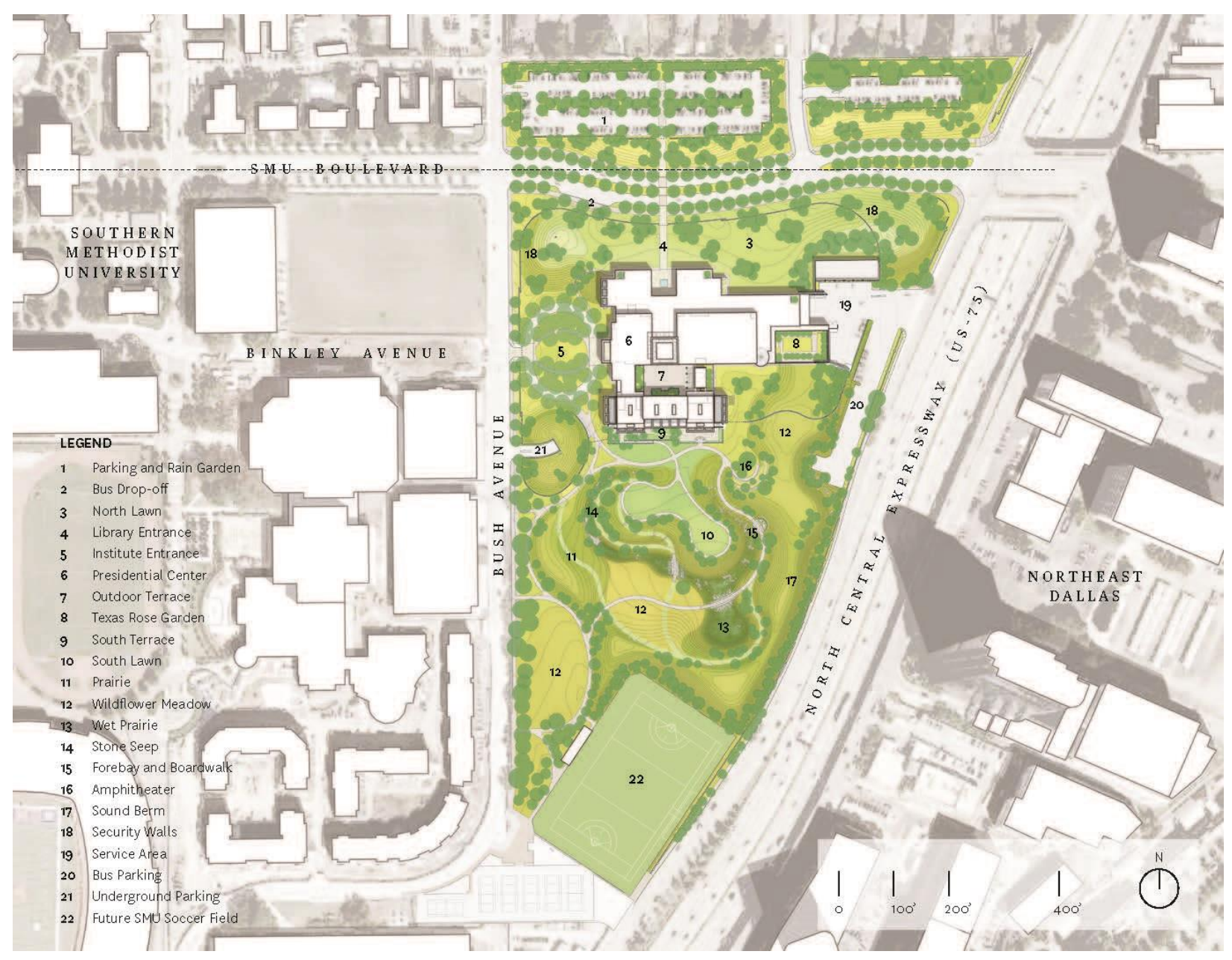

\section{Performance Measures}




\section{Environmental Benefits}

Treats more than $90 \%$ of average annual rainfall to remove an estimated $85 \%$ of total suspended solids.

\section{Background}

The George W. Bush Presidential Center (GWBPC) landscape incorporates an intricate water management system throughout the entire 24 acres of the site. All rainwater from the parking lots and building flows through the system along limestone seeps and bioswales, eventually collecting in a wet prairie at the end of the site. Below the wet prairie is a 250,000 gallon underground cistern. As water flows through water management systems, it is filtered and cleaned by soil and vegetation.

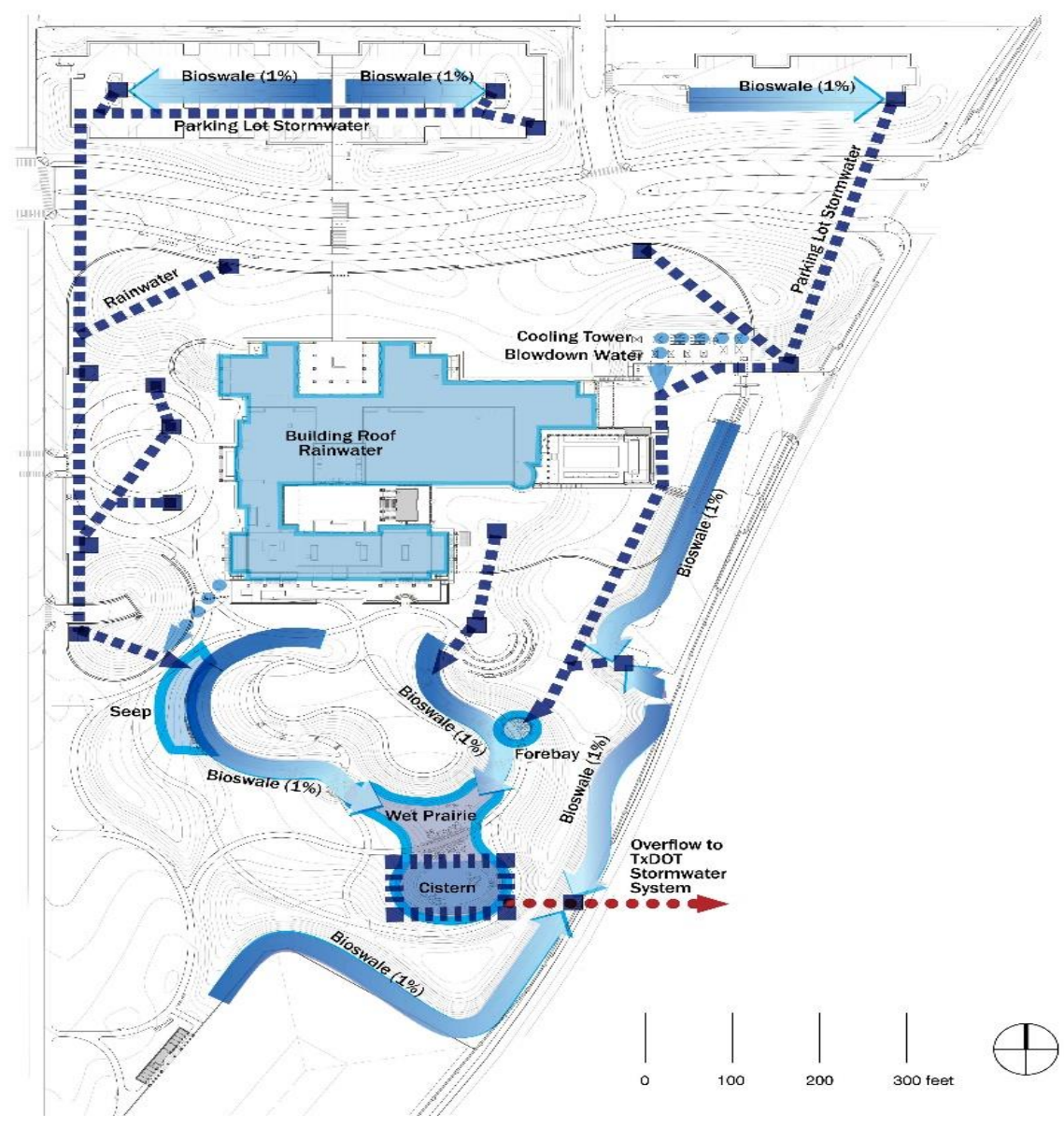

\section{Methods}

Data is collected from the LEED application compiled by the civil engineer, URS Corp. The engineer team first calculated the required drainage of the site based on the LEED requirements. The volumes treated by the different bioswales were then calculated. 


\section{Calculations}

Step 1 REQUIRED DRAINAGE

$976,500 \mathrm{ft}^{2} \times 0.75$ in $X 1 \mathrm{ft} / 12$ in $=61031.25 \mathrm{ft}^{3} \times 7.48 \mathrm{gal} / \mathrm{ft}^{3}$

$=456,513.75$ gallons $\leftarrow 90 \%$ average rainfall

\section{Step 2 AMOUNT OF AVERAGE TREATED PER BEST MANAGEMNET PRACTICE (BMP)}

Parking Bioswale $A=$ area collected $=54014 \mathrm{ft}^{2} \times 0.75$ in $/ 12 \mathrm{ft}=3,376 \mathrm{ft}^{3}$

$=\mathbf{2 5 , 2 5 1}$ gallons $/ 456,514$ gallons $=\mathbf{5 . 5 3} \%$ of average rainwater on site treated by parking bioswale $A$

Parking Bioswale $B=36,590.4 \mathrm{ft}^{2} \times 0.75 \mathrm{in} / 12 \mathrm{ft}=2,286.9 \mathrm{ft}^{3}$

$=\mathbf{1 7}, \mathbf{1 0 6}$ gallons $/ 456,514$ gallons $=\mathbf{3 . 7 5} \%$ of average rainwater on site treated by parking bioswale $B$

Parking Bioswale $C=44,866.8 \mathrm{ft}^{2} \times 0.75 \mathrm{in} / 12 \mathrm{ft}=2,804.175 \mathrm{ft}^{3}$

$=26,880$ gallons $/ 456,514$ gallons $=4.59 \%$ of average rainwater on site treated by parking bioswale $C$

Parking Bioswale $D=57,500 \mathrm{cX} 0.75 \mathrm{in} / 12 \mathrm{ft}=3,593.7 \mathrm{ft}^{3}$

$=\mathbf{2 6 , 8 8 0}$ gallons $/ 456,514$ gallons $=\mathbf{5 . 8 9} \%$ of average rainwater on site treated by parking bioswale $D$

Parking Bioswale $E=27,007 \mathrm{ft}^{2} \times 0.75 \mathrm{in} / 12 \mathrm{ft}=1,687.95 \mathrm{ft}^{3}$

$=\mathbf{1 2}, \mathbf{6 2 6}$ gallons $/ 456,514$ gallons $=\mathbf{2 . 7 7 \%}$ of average rainwater on site treated by parking bioswale $\mathrm{E}$

Site Bioswale $A=211,266 \mathrm{ft}^{2} \times 0.75 \mathrm{in} / 12 \mathrm{ft}=13,204 \mathrm{ft}^{3}$

$=\mathbf{9 8 , 7 6 6}$ gallons $/ \mathbf{4 5 6 , 5 1 4}=\mathbf{2 1 . 6 3} \%$ of average rainwater on site treated by site bioswale $A$

Site Bioswale $B=266,587.2 \mathrm{ft}^{2} \times 0.75 \mathrm{in} / 12 \mathrm{ft}=16,661 \mathrm{ft}^{3}$

$=\mathbf{1 2 4}, \mathbf{6 2 9}$ gallons $/ 456,514$ gallons $=\mathbf{2 7 . 3} \%$ of average rainwater on site treated by site bioswale $B$

Site Bioswale $C=35,283.6 \mathrm{ft}^{2} \times 0.75 \mathrm{in} / 12 \mathrm{ft}=2,205.225 \mathrm{ft}^{3}$

$=\mathbf{1 6 , 4 9 9}$ gallons $/ 456,514$ gallons $=\mathbf{3 . 6 1} \%$ of average rainwater on site treated by site bioswale $\mathrm{C}$

Wet Prairie $=659,063 \mathrm{ft}^{2} \times 0.75 \mathrm{in} / 12 \mathrm{ft}=41,191 \mathrm{ft}^{3}$

$=\mathbf{3 0 8 , 1 1 1}$ gallons $/ 456,514$ gallons $=\mathbf{6 7 . 4 9} \%$ of average rainwater on site treated by wet prairie

$\underline{\text { Totals }}$

$5.53 \%+3.75 \%+4.59 \%+5.89 \%+2.77 \%+21.63 \%+27.3 \%+3.61 \%+67.49 \%=142.56 \%$ of average rainwater on site treated by BMPs

25,251 gallons $+17,106$ gallons $+26,880$ gallons $+26,880$ gallons $+12,626$ gallons $+98,766$ gallons $+124,629$ gallons $+16,499$ gallons $=\mathbf{6 5 6 , 7 4 8}$ gallons treated by BMPS

656,748 gallons (actual) / 456,514 gallons (required) $=1.44$

Note that because the systems operated in series, most of the water is treated by more than one $B M P$. 


\begin{tabular}{|c|c|c|c|c|}
\hline $\begin{array}{l}\text { Best Management } \\
\text { Practice (BMP) }\end{array}$ & $\begin{array}{l}\text { Description of BMP's } \\
\text { Contribution to Stormwater } \\
\text { Filtration }\end{array}$ & \begin{tabular}{|l|} 
TSS Removal \\
Efficiency (\%)
\end{tabular} & $\begin{array}{l}\text { \% of Annual } \\
\text { Rainfall Treated } \\
\text { by BMP }\end{array}$ & $\begin{array}{l}\text { Source of TSS Removal } \\
\text { Efficiency data }\end{array}$ \\
\hline Parking Area Bioswale & $\begin{array}{l}\text { A vegetated filter strip captures } \\
\text { water }\end{array}$ & 65 & 5.53 & National or regional sources \\
\hline Parking Area Bioswale & $\begin{array}{l}\text { A vegetated filter strip captures } \\
\text { water }\end{array}$ & 65 & 3.75 & National or regional sources \\
\hline Parking Area Bioswale & $\begin{array}{l}\text { A vegetated filter strip captures } \\
\text { water }\end{array}$ & 65 & 4.59 & National or regional sources \\
\hline Parking Area Bioswale & $\begin{array}{l}\text { A vegetated filter strip captures } \\
\text { water }\end{array}$ & 65 & 5.89 & National or regional sources \\
\hline Parking Area Bioswale & $\begin{array}{l}\text { A vegetated filter strip captures } \\
\text { water }\end{array}$ & 65 & 2.77 & National or regional sources \\
\hline Site Bioswale A & $\begin{array}{l}\text { A vegetated filter strip captures } \\
\text { water }\end{array}$ & 65 & 21.63 & National or regional sources \\
\hline Site Bioswale B & $\begin{array}{l}\text { A vegetated filter strip captures } \\
\text { water }\end{array}$ & 65 & 27.3 & National or regional sources \\
\hline Site Bioswale C & $\begin{array}{l}\text { A vegetated filter strip captures } \\
\text { water }\end{array}$ & 65 & 5.35 & National or regional sources \\
\hline Wet Prairie & $\begin{array}{l}\text { An extended detention wet } \\
\text { prairie }\end{array}$ & 40 & 67.49 & National or regional sources \\
\hline \multirow{2}{*}{\multicolumn{3}{|c|}{$\begin{array}{l}\text { Weighted average TTS Removal efficiencey for } 90 \% \text { for annual rainfall } \\
\text { treated (\%) (must be at least } 80 \% \text { ) }\end{array}$}} & 85.47 & \\
\hline & & & 144 & \\
\hline
\end{tabular}

\section{Limitations}

The calculations are based on a 2 year storm event and do not account for larger storm events. The TTS removed is an estimation. The efficiency of pollutant removal can change over time.

\section{Reference}

- "SS Credit 6.2: Stormwater Design - Quality Control", LEED for New Construction Design, Jeffrey L. Bruce \& Company, LLC

- Green Building Design and Construction. Washington, DC: U.S. Green Building Council, 2009. Print.

\section{Reduces potable water consumption for irrigation by $73 \%$ or 6.126 million gallons per year compared to a baseline case.}

\section{Background}

The George W. Bush Presidential Center (GWBPC) landscape incorporates an intricate water management system throughout the entire 24 acres of the site. All rainwater from the parking lots and building flows through the system along limestone seeps and bioswales, eventually collecting in a wet prairie at the end of the site. Below the wet prairie is a 250,000 gallon underground cistern. These water recycling techniques have successfully decreased the irrigation volume originally predicted for this project. 
Calculations for the LEED baseline water quantities were generated by the irrigation designer, Jeffrey L. Bruce \& Company, LLC, on the project for the LEED application process.

\section{Methods}

The LEED baseline case is calculated using average values for regional evapotranspiration rate (ETO), species factor (ks), density factor (kd) and microclimate factor $(\mathrm{kmc})$ for each vegetation type and equipment used on the project.

\begin{tabular}{|c|c|c|}
\hline Month & Potable water (gallons) & LEED Baseline \\
\hline March '14 & 264,000 & 553,555 \\
\hline April '14 & - & 700,529 \\
\hline May '14 & - & $1,021,948$ \\
\hline June '14 & - & $1,153,812$ \\
\hline July '14 & 127,000 & $1,192,273$ \\
\hline August '14 & 357,000 & $1,107,110$ \\
\hline September '14 & $1,312,000$ & 824,152 \\
\hline October '14 & 191,000 & 569,136 \\
\hline November '14 & - & 370,868 \\
\hline December '14 & 1,000 & 255,487 \\
\hline January ‘15 & - & 255,487 \\
\hline February '15 & - & 346,144 \\
\hline $\begin{array}{l}\text { Total Observed } \\
\text { Demand }\end{array}$ & $2,252,000$ & $8,377,501$ \\
\hline $\begin{array}{l}\% \text { reduction in actual } \\
\text { water used compared } \\
\text { to estimation }\end{array}$ & $73 \%$ & \\
\hline
\end{tabular}

$8,377,501-2,252,000=6,125,501$ gallons

\section{Limitations}

Though the observed demand is a true observation of water use, the LEED baseline calculations are an estimation.

\section{Reference}

- Data Source, Jeffrey L. Bruce \& Company, LLC, March 26th, 2015

- Green Building Design and Construction. Washington, DC: U.S. Green Building Council, 2009. Print.

- Http://www.usgbc.org/credits/existing-buildings/v2009/wec3. N.p., n.d. Web. 24 July 2015. 


\section{Achieves a Biomass Density Index - a measure of the density of plant layers covering the ground - of 3.24 for vegetated areas of the site, $62 \%$ higher than that of a traditional lawn.}

\section{Background}

Biomass density index (BDI) is a measure of vegetation development appropriate to the specific regional climate.

"Environmental, economic, and social benefits emerge from all general characteristics of living vegetation, such as shading of structures or recreational spaces, atmospheric and building cooling, building protection from cold or otherwise damaging winds, reduced soil water evaporation (hence reducing irrigation), improved air quality (absorption of particulate PM10 and PM20 and low level ozone), noise reduction, storm run-off reduction (from improved soil permeability and vegetation canopy interception and transpiration), and improved water quality (as runoff or sub-soil recharge)." (Sites V2 Reference Guide, p.135)

\section{Methods}

The Biomass density index is calculated using the methods described in the Sites V2 Reference Guide.

1. Draw a map of the zones of land cover or vegetation types on site. Determine the percent of total area for each distinct zone.

2. Decide on a vegetated area or land cover zone categorized in the Sites reference book, areas should not overlap

3. Exclude areas of open water or invasive species

To be most meaningful for the purposes of comparing this site to a more traditional institutional site with vast areas of lawn, the $B D I$ reported in the benefit is the BDI for the vegetated areas of the site - it was calculated without including the impervious areas (building, parking lots).

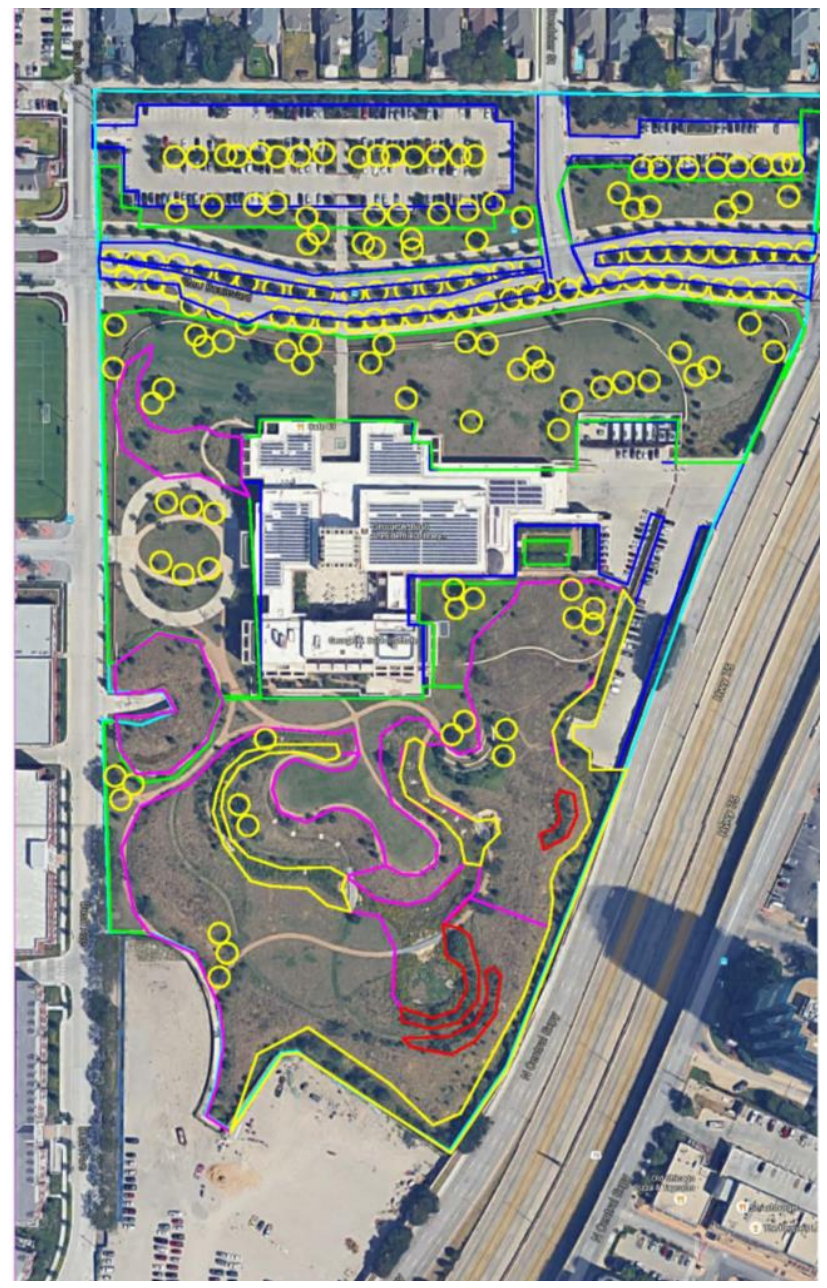




\begin{tabular}{|l|l|l|l|l|l|}
\hline $\begin{array}{l}\text { Land cover/vegetation } \\
\text { type zone }\end{array}$ & $\begin{array}{l}\text { Biomass } \\
\text { density } \\
\text { value* }\end{array}$ & $\begin{array}{l}\text { Percent of } \\
\text { total site } \\
\text { area }\end{array}$ & $\begin{array}{l}\text { Biomass density value } \\
\text { x percent total site } \\
\text { area } \\
\text { (column B x column C) }\end{array}$ & $\begin{array}{l}\text { Percent of total } \\
\text { vegetated area } \\
\text { of site }\end{array}$ & $\begin{array}{l}\text { Biomass density value } \\
\text { x percent total } \\
\text { vegetated area } \\
\text { (column B x column E) }\end{array}$ \\
\hline A & B & C & D & E & F \\
\hline Tree understory & 6 & $13.13 \%$ & 0.786 & $18.02 \%$ & 1.081 \\
\hline Shrubs & 3 & $8.05 \%$ & 0.242 & $11.05 \%$ & 0.331 \\
\hline $\begin{array}{l}\text { Managed turf } \\
>3 \text { "(Habiturf }\end{array}$ & 3 & $22.02 \%$ & 0.661 & $30.21 \%$ & 0.906 \\
\hline $\begin{array}{l}\text { Unmanaged grass } \\
\text { layer (prairie/pasture) } \\
>9 \text { " }\end{array}$ & 2 & $28.62 \%$ & 0.572 & $39.27 \%$ & 0.785 \\
\hline Wetland & 6 & $1.62 \%$ & 0.097 & $2.22 \%$ & 0.133 \\
\hline $\begin{array}{l}\text { Impervious cover } \\
\text { (includes building } \\
\text { footprint) }\end{array}$ & 0 & $27.12 \%$ & 0 & - & \\
\hline BDI for whole site & & & 2.36 & & 3.24 \\
\hline $\begin{array}{l}\text { BDI for vegetated } \\
\text { areas only }\end{array}$ & & & & & \\
\hline
\end{tabular}

A typical lawn would be classified as Managed turf $<3$ ", which has a BDI of 2 .

$(3.24-2) / 2=62 \%$ higher BDI than a traditional lawn

Limitations

Vegetation type areas are an approximation.

\section{References}

- $\quad$ "Google Maps." Google Maps. N.p., n.d. Web. 20 June 2015.

- $\quad$ SITES V2 Reference Guide: For Sustainable Land Design and Development. Austin, TX: Sustainable Sites Initiative, n.d. Print. 2014

- The Bagby Street Reconstruction Project Planting Plan from Design Workshop's Construction Documents

\section{$\underline{\text { Social Benefits }}$}

\section{Helped attract over 819,488 visitors to the Presidential Center in the first two years since it opened.}

\section{Background}


Although the site offers docent led educational tours for children or adults, data on the number of tours is not yet collected. The only occupancy data collected is the number of people who have visited the facility since opening in April 2013.

\section{Data}

GWBPC opened: April 2013

Data Collected: July 2015

Number of visitors since opening: 819, 488

\section{Limitations}

The park is open to the public which makes monitoring the number of patrons difficult. Visitors who did not enter the site through the library are not accounted for in this benefit. The data reflects the number of people who visited the presidential library building. This does not ensure that all these patrons went outside into the landscape.

\section{References}

- Data source, Operations Director at the George W. Bush Presidential Library

\section{$\underline{\text { Economic Benefits }}$}

\section{Saved \$821,000 in disposal costs by using all 100,000 cubic yards of excavated soil} on-site.

\section{Background}

The 100,000 cubic yards of fill from building construction was used on-site instead of disposed of in a landfill. Doing so saved money on construction costs, it also saved space in the landfill and reduced the project's carbon emission footprint.

\section{Methods}

Numbers on cubic yards of fill provided by MVVA. The general contractor bids $\$ 8.21$ per cubic yard for disposing excavated soil off-site.

\section{Data}

100,000 cubic yards $X \$ 8.21=\$ 821.000$

\section{Limitations}

Calculations on the amount of fill are an estimate. This metric does not deduct the costs of moving fill around the site to create desired topography.

\section{References}

- Data source, Bid for soil removal, Manhattan Construction Contractor

- Personal communication, Herb Sweeny IV, Senior Associate, Michael Van Valkenburgh Associates Inc.

Reduces lawn mowing costs by approximately $\$ 41,160$ by using native Habiturf ${ }^{m}$, which requires only 4 mowings per year. 


\section{Background}

The specially formulated short-prairie grass mixture of the native lawn is composed of buffalo grass, blue grama, texas grama, poverty dropseed, and curly mesquite. The lawn is maintained at 6-8 inches and mowed only four times a year. The nearly 9 acre lawn represents the largest use of Habiturf ${ }^{\mathrm{TM}}$.

\section{Methods}

A standard lawn is mowed approximately 25 times per year. Calculations are made with this standard and the costs to mow the lawn at the GWBPC provided by the maintenance contractors.

\section{Data}

$\$ 1,960 /$ mowing

4 mowings a year $=4 \times \$ 1,960=\$ 7,840$

25 mowings a year $=25 \times \$ 1,960=\$ 49,000$

$\$ 49,000-\$ 7,840=\$ 41,160$

\section{Limitations}

The landscape at the GWBPC is treated in a holistic matter which supports the soil's food web. Only organic treatments are used and nearly no pesticides. As a result, manual hand-weeding is required until there is full establishment of native species and the desired ecosystems. The hand-weeding is costly but preferred to herbicides because it supports the design intent of the project which is to create working ecosystems with healthy soils.

\section{References}

- Data Source, Maintenance bid from Southern Botanical Contractor

- "Habiturf." Lady Bird Johnson Wildflower Center. University of Texas at Austin. n.d. Web. 17 September

- "The Landscapes of the George W. Bush Presidential Center" Commemorative Book, Michael Van Valkenburgh Associates, Inc., 2013

\section{Reduced water costs by $\$ 1,846.70$ during peak irrigation times with water recycling systems}

\section{Background}

The LEED platinum certified building at the GWBPC recycles water to the landscape from the cooling towers and roof top rainwater collectors. In addition, water collected on the landscape is circled back to irrigate plantings.

\section{Methods}

Data on water usage was collected for the "Peak Irrigation Demand Detailed Non-potable Water Use Source" calculations compiled by the engineering group Jeffrey L. Bruce \& Company, LLC. Costs for water in the City of University Park, TX were provided by the Director of Operations of the GWBPC. The non-potable water collected and used is given a nominal value to show savings. 


\section{Data}

July water use

Irragation Desin Case (July)

Subtotal TWA (gallons):

$1,057,408$

Non-potable water use (July)

Cooling tower Blowdown (gallons)

110,357

Roof (gallons)

124,722

Site (gallons)

77,921

Total non-potable water use: $\quad 313,000$

Irrigation Design Case TPWA (gallons) $\quad \mathbf{7 4 4 , 4 0 8}$

Water costs

Consumption charge: $\$ 4.30$ per 1,000 gallons consumed

Conservation surcharge: During the months of May through October, an additional

$\$ 1.60 / 1,000$ gallons is assessed for all consumption over 30,000 gallons/month

$(30,000 / 1,000) \times \$ 4.30=\$ 129$

313,000 gallons $-30,000$ gallons $=283,000$ gallons

$\$ 4.30+\$ 1.60=\$ 5.90$

$(283,000$ gallons $/ 1,000) \times \$ 5.90=\$ 1,669.70$

$\$ 129+\$ 1,669.70=\$ 1,798.7$

\section{Limitations}

Data on non-potable water use was only available for one month during peak irrigation times. Months during low irrigation times would exhibit a higher savings.

\section{References}

- Data source, City of University Park municipal water charges, July, 2015

- "Peak Irrigation Demand Detailed Non-potable Water Use Source”, Jeffrey L. Bruce \& Company, LLC, July, 2015

\section{Cost Comparison}

\section{Background}

The pedestrian bridges on this project are made of black locust (Robinia pseudoacacia), a species favored by the MVVA firm. Black locust is a hardwood comparable to tropical hardwoods, such as ipa, and known for its rot and insect resistance. Unlike tropical woods, black locust is grown locally which decreases the carbon footprint of transportation and does not lead to rainforest degradation. Black locust lasts longer than pressure treated wood. Pressure treated wood, such as cedar or pine, is treated with various Red List chemicals. The 
lumber used on the GWBPC is sourced from black locust Lumber a vendor located in Pennsylvania.

\section{Methods}

The firm provided cost of the total black locust lumber bid. Using bridge dimensions, the cost per plank was calculated. This cost was compared to a typical pressure treated lumber of similar dimension. The pressure treated wood has been treated with Copper Azole.

\section{Data}

\begin{tabular}{|c|c|c|c|c|c|c|}
\hline Bridge & Length (ft) & \multicolumn{2}{|c|}{ Width (ft) } & \multicolumn{2}{|c|}{$\begin{array}{l}\text { Approximate number of } \\
\text { black locust } 4 \times 8 \times 8 \text { planks }\end{array}$} & Approximate Costs \\
\hline$A$ & 60 & & 8 & & 90 & $\$ 15,233$ \\
\hline B & 42 & & 8 & & 63 & $\$ 10,663.22$ \\
\hline \multirow[t]{2}{*}{ C } & 100 & & 8 & & 150 & $\$ 25,388.61$ \\
\hline & & & & & & $\$ 51,285$ \\
\hline \multicolumn{7}{|c|}{ Black Locust $4 \times 8 \times 8 \mathrm{ft}$} \\
\hline Total Cost & $\$ 51,285$ & & & & & \\
\hline Total planks & 303 & & & & & \\
\hline \multirow[t]{2}{*}{ Cost per plank } & $\$ 169.26$ & & & & & \\
\hline & $\begin{array}{l}\text { Cost per } \\
\text { plank }\end{array}$ & & $\begin{array}{l}\text { Total cost } \\
\text { planks }\end{array}$ & for 303 & & \\
\hline black locust & $\$ 169$ & 9.26 & & $\$ 51,285.00$ & & \\
\hline \multirow[t]{2}{*}{ pressure treated } & $\$ 44$. & 4.97 & & $\$ 13,625.91$ & & \\
\hline & Cost differ & rnce & & $\$ 37,659.09$ & & \\
\hline
\end{tabular}

\section{Limitations}

The dimension of the black locust planks used on the bridges $(4 \times 8 \times 8 \mathrm{ft})$ is not a standard dimension for lumber. The pressure treated wood used to compare costs is a $4 \mathrm{X} 8 \mathrm{X} 12 \mathrm{ft}$ dimension. A more in-depth study would incorporate service lifetimes for each type of lumber.

\section{References}

- $\quad$ Green, Jared. "Why Use Ipe When You Can Have Black Locust?" The Dirt. ASLA, 10 Nov. 2011. Web. 15 July 2015.

- "The Landscapes of the George W. Bush Presidential Center" Commemorative Book, Michael Van Valkenburgh Associates, Inc., [not published]

- Product Display. Lowes, n.d. Web. 13 July 2015.

- $\quad$ "Sustainability" Black Locust Lumber, U.S.A. N.p., n.d. Web. 13 July 2015. 